\title{
The Students' Interest in Online Learning in Higher Education During the Covid-19 Pandemic
}

\author{
Dafid Slamet Setiana $^{1}$, Betty Kusumaningrum ${ }^{1, \text { a) }}$, Riawan Yudi Purwoko ${ }^{2}$ \\ ${ }^{1}$ Universitas Sarjanawiyata Tamansiswa \\ Batikan UH-III/1043 Street, Tuntungan, Umbulharjo, Yogyakarta, Special Region of Yogyakarta, Indonesia, \\ 55167 \\ ${ }^{2}$ Universitas Muhammadiyah Purworejo \\ 3 \& 6 K. H. Ahmad Dahlan Street, Purworejo, Purworejo, Purworejo, Central Java, Indonesia, 54151
}

a) betty.kusumaningrum@ustjogja.ac.id

\begin{abstract}
The Covid-19 pandemic in various countries has had an impact on changes in the education system. The implementation of learning has changed from classroom to online learning. The implementation of online learning certainly affects the learning interest of students. This study was conducted to determine student interest in learning during the Covid-19 pandemic. The subjects in this study were students of the Mathematics Education Study Program at a private university in Yogyakarta; as many as 72 students were selected using the simple random sampling method. The data in this study were collected through a Google Form questionnaire. The questionnaire contains 15 items of multiple-choice and each item contains a "why" question to obtain in-depth data about the answers given by respondents. The data of the questionnaire was analyzed descriptively qualitatively. The results indicated that students' interest in online learning needed to be increased. It can be seen from students' responses to the questionnaire that only $15.3 \%$ of students gave a positive response to online learning and $32 \%$ to online exams. In general, students prefer classroom learning compared to online learning in student attendance, lecturer-student interaction, and technical learning. Online learning tends to reduce student interest in attending lectures. Limitations of internet access, lecturer delivery methods, and the number of workloads are factors causing the decline in student interest. By knowing students' interest in learning and the factors that cause low interest in learning, lecturers can improve the quality of learning to increase student interest in online learning.
\end{abstract}

Keywords: Covid-19 Pandemic; Learning Interest; Online Learning

\begin{abstract}
Abstrak. Pandemi Covid-19 di berbagai negara membawa perubahan pada sistem pendidikan. Pelaksanaan pembelajaran telah berubah dari pembelajaran tatap muka menjadi pembelajaran daring. Penerapan pembelajaran daring tentunya mempengaruhi minat belajar mahasiswa. Penelitian ini dilakukan untuk mengetahui minat belajar mahasiswa selama masa pandemi Covid-19. Subjek dalam penelitian ini adalah mahasiswa Program Studi Pendidikan Matematika pada salah satu perguruan tinggi swasta di Yogyakarta sebanyak 72 orang yang dipilih dengan menggunakan metode Simple Random Sampling. Data dalam penelitian ini dikumpulkan melalui kuesioner Google Form. Kuesioner berisi 15 item pilihan ganda dan setiap item memuat pertanyaan "mengapa" untuk memperoleh data yang mendalam mengenai jawaban yang diberikan oleh responden. Data kuesioner kemudian dianalisis secara deskriptif kualitatif. Hasil penelitian menunjukkan bahwa minat belajar mahasiswa dalam pembelajaran daring perlu ditingkatkan. Hal ini terlihat dari tanggapan mahasiswa terhadap kuesioner bahwa hanya $15,3 \%$ mahasiswa yang memberikan tanggapan positif terhadap pembelajaran daring dan $32 \%$ terhadap ujian secara daring. Pada umumnya mahasiswa lebih menyukai pembelajaran tatap muka dibandingkan dengan pembelajaran daring dalam hal kehadiran mahasiswa, interaksi dosen-mahasiswa, dan teknis pembelajaran. Pembelajaran daring cenderung menurunkan minat mahasiswa untuk mengikuti perkuliahan. Keterbatasan akses internet, metode penyampaian dosen dan banyaknya beban tugas menjadi faktor penyebab turunnya minat mahasiswa. Dengan mengetahui minat belajar mahasiswa dan faktor penyebab rendahnya minat belajar mahasiswa, dosen dapat meningkatkan kualitas pembelajaran untuk meningkatkan minat mahasiswa terhadap pembelajaran daring.
\end{abstract}

Kata kunci: Minat Belajar; Pandemi Covid-19; Pembelajaran Daring 


\section{INTRODUCTION}

In 2019, various countries, including Indonesia, experienced disease outbreaks caused by the coronavirus (Nadeem, 2020; Kusumaningrum \& Wijayanto, 2020). Indonesia confirmed the first case on $2^{\text {nd }}$ March 2020 (Setiawan, 2020; Setiawan \& Ilmiyah, 2020; Tosepu et al., 2020). On $11^{\text {th }}$ March 2020, WHO declared a global pandemic (Cucinotta \& Vanelli, 2020). It was recorded that on 21 st March 2020, as many as 167 countries had confirmed cases of Covid-19 with a total positive case of more than 285.000 people, and as many as 12.000 people died (Clerkin, Fried, \& Raikhelkar, 2020; Hermansyah, 2020). Until $16^{\text {th }}$ May 2020, the number of positive cases of Covid19 in Indonesia was 16.496 people (Kemenkes RI, 2020). Due to the continued increase in positive cases of Covid-19 in Indonesia, the Indonesian government is trying to stop the spread of Covid-19 by implementing the Enforcement of Community Activity Restrictions (Gunawan, Suranti \& Fathoroni, 2020; Khasanah, Pramudibyanto \& Widuroyekti, 2020). One of the policies implemented is the implementation of online learning (Anhusadar, 2020; Pratiwi, 2020, Hikmat et al., 2020).

The policy of implementing online learning is applied to all levels of education, from primary to higher education (Kusumaningrum, Kuncoro \& Arigiyati, T. A., 2020). Online learning is implemented at the higher education level based on the Circular Letter of the Ministry of Education and Culture of the Directorate General of Higher Education Number 1 of 2020 concerning Prevention of the Spread of Covid-19 in Higher Education (Kemendikbud, 2020). Online learning during the pandemic is an alternative solution as an effort to break the chain of the spread of Covid-19 (Basilaia \& Kvavadze, 2020; Bauerlein, 2008; Laprairie \& Hinson, 2006; Taha et al., 2020). However, the implementation of online learning may cause new problems in education (Hung \& Chou, 2015; Smart \& Cappel, 2006; Van Bruggen, 2005).

The implementation of online learning has some strengths and weaknesses. The weaknesses of online learning implementation tend to reduce student interest in learning (Kusumaningrum, Kuncoro, Sulistyowati \& Arigiyati, 2021). Learning interest is a crucial factor in the learning process. Without any student learning interest, the learning objectives will not be achieved (Sutriyani, 2020). Interest can also predict students' motivation for learning and encourage students to give a positive effect (Bye, Pushkar, \& Conway, 2007). Hidi and Ainley (2020) highlight that if students have an interest in learning, students will feel enjoy learning. It suggests that learning interest is important because it is a key driver of engagement for students. Students are getting bored with online learning (Santika, Sutisnawati \& Uswantun, 2020), it can impact student achievement certainly (Yunitasari \& Hanifah, 2020; Kurniawan \& Makin, 2021). Many researchers are interested in researching student interest in online learning. However, no one has researched first-year college students before. This research aims to determine student interest in online 
learning in terms of student attendance, the interaction of lecturer-students, and technical learning. By knowing students' interest in learning and the factors that cause low interest in learning, lecturers can improve the quality of learning to increase student interest in the online learning method.

\section{METHOD}

This research was conducted on Mathematics Education students who are taking the $2^{\text {nd }}$ semester and $4^{\text {th }}$ semester in the $2020 / 2021$ academic year at a private university in Yogyakarta. Respondents in this study were 72 students who were selected by the Simple Random Sampling method. The primary data in this study was obtained using a Google Form questionnaire. The questionnaire was available online from $12^{\text {th }}-26^{\text {th }}$ May 2021. The secondary data was obtained by studying literature to obtain information related to online learning during the Covid-19 pandemic. Before being used, the questionnaire was validated by two lecturers. The purpose of validation was to find out whether the instrument could be measuring what is desired. The overall test validation results are excellent (see Table 1), so the questionnaire is feasible to use.

Table 1. Summary of Test Validation Results

\begin{tabular}{cccc}
\hline No. & Component & Average & Criteria \\
\hline 1. & Content & 10 & Very good \\
\hline 2. & Construction & 24 & Very good \\
\hline 3. & Language & 15 & Very good \\
\hline
\end{tabular}

The questionnaire contains 15 items of multiple-choice that consist of 11 positive items and four negative items with two answer choices that students must fill out with Yes or No. For every item of questions, there was a "why" question to obtain in-depth data regarding the answers given by respondents. Responses to the open-ended questions were transcribed and categorized to obtain generalizations from the honest answer. Then, each multiple-choice answer of respondents is given a score. The provisions for scoring the respondents' answers are shown in Table 2.

Table 2. Scoring Terms

\begin{tabular}{ccc}
\hline \multirow{2}{*}{ Answer Options } & \multicolumn{2}{c}{ Respondent's Answer Score } \\
\cline { 2 - 3 } & Positive & Negative \\
\hline Yes & 1 & 0 \\
\hline No & 0 & 1 \\
\hline
\end{tabular}

Qualitative research is used to provide concrete data on how students are interested in online learning. The primary purpose of this study was to gather evaluative feedback from students on their experience and perception about online learning to find out how students are interested in participating in online learning. After obtaining the data, then it was analyzed descriptively qualitatively. 


\section{RESULTS AND DISCUSSION}

The questionnaire results showed students' interest assessed from several indicators: seriousness, effort, convenience, and enthusiasm in online learning. The seriousness of students in learning and doing assignments can be seen in Table 3 .

Table 3. The seriousness of Students in Learning and Doing Assignments

\begin{tabular}{clcc}
\hline \multirow{2}{*}{ No. } & \multicolumn{1}{c}{ Questions } & \multicolumn{2}{c}{ Respondent's answer (\%) } \\
\cline { 3 - 4 } & & Yes & No \\
\hline 1. & $\begin{array}{l}\text { The existence of a government policy to study from home reduce } \\
\text { your enthusiasm for attending lectures? }\end{array}$ & 73.6 & 26.4 \\
\hline 2. & Do you prioritize time for studying every day? & 87.5 & 12.5 \\
\hline 3. & Do you take online assignments seriously? & 70 & 30 \\
\hline 4. & Have you ever been late in submitting an online assignment? & 14.1 & 85.9 \\
\hline 5. & Have you ever felt pressured because of many tasks? & 55.3 & 44.7 \\
\hline
\end{tabular}

Table 3 shows the seriousness of students in learning and doing online assignments. The questionnaire results in point (1) can be concluded that "learn from home" reduces students' enthusiasm to attend online learning. They said that online learning feels very dull. In online learning, the limited lecturer-student interaction and signal interference are the reasons. In the results of her research, Gumanti \& Teza (2021) stated that most students felt compelled to take online lectures (69.3\%). Students are bored studying and doing assignments at home and cannot interact with teachers and friends as usual (Santika, Sutisnawati \& Uswantun, 2020). Online learning did not seem practical compared to the classroom method because of teacher-student disconnect, lack of interaction, inability to engage the group, and technical issues (Nambiar, 2020). At points (2-4), it is concluded that students give good attention to their learning obligations and the tasks. Students keep learning, doing assignments, and submitting them on time, just like classroom learning (Saifuddin, 2018). They did it to get good grades in online learning. Gumanti \& Teza (2021) supports this statement by saying that students do every task in online learning with a percentage of $72.7 \%$. The results obtained in point (5) can be concluded that the immense task load reduces student interest in online learning. The constant pressure to complete assignments puts many students under pressure. Students feel that from the task, there is no transfer of knowledge. The seriousness of students in studying and doing assignments needs attention from researchers and lecturers because the percentage of students who are less interested in learning and doing online assignments is relatively high (Limbong \& Simarmata, 2020).

Student interest in learning is also measured by the effort made by students when experiencing difficulties. A genuine effort in learning shows a high interest in learning. The level of effort made by students when experiencing difficulties can be seen in Table 4 . 
EDUMATIKA : Jurnal Riset Pendidikan Matematika

Table 4. Efforts Made by Students When Experiencing Difficulties

\begin{tabular}{cllc}
\hline & \multicolumn{1}{c}{ Questions } & \multicolumn{2}{c}{ Respondent's answer (\%) } \\
\cline { 3 - 4 } No. & & Yes & No \\
\hline 6. & $\begin{array}{l}\text { Do you copy the answer to a friend's assignment when you have } \\
\text { trouble doing your homework? }\end{array}$ & 88.6 & 11.4 \\
\hline 7. $\quad$ Will you be silent when you do not understand the lesson? & 23.6 & 76.4 \\
\hline 8. $\quad \begin{array}{l}\text { Do you looking for information on the internet to increase your } \\
\text { knowledge? }\end{array}$ & 67.2 & 32.8 \\
\hline 9. $\quad \begin{array}{l}\text { When you are experiencing difficulties, do you try to ask a friend } \\
\text { via chat? }\end{array}$ & 89.4 & 10.6 \\
\hline
\end{tabular}

Table 4 shows that when experiencing difficulties, students will make efforts to overcome various difficulties. Seen from the percentage, the effort students most often make is copying the answer of a friend's assignment. The results of Gumanti \& Teza's research (2021) support this finding, where $51.5 \%$ of students will copy their friends' assignments when they have difficulty completing the tasks. This fact certainly can be a weakness of online learning: the level of plagiarism is relatively high. From Table 3, it can also be concluded that when experiencing difficulties, students tend to prefer to ask friends rather than look for information on the internet (Google, YouTube). This fact indicates that the literacy level of students is still relatively low.

Convenience in the learning process can also be an indicator of student interest in taking online learning. Availability of internet access, method of delivering lessons by lecturers, the response of lecturers to students, and type of assignments provide an overview of student interest in online learning (Table 5).

Table 5. Convenience in Attending Lectures

\begin{tabular}{|c|c|c|c|}
\hline \multirow{2}{*}{ No. } & \multirow{2}{*}{ Questions } & \multicolumn{2}{|c|}{ Respondent's answer (\%) } \\
\hline & & Yes & No \\
\hline 10. & $\begin{array}{l}\text { Are you bothered by limited internet access while studying } \\
\text { online? }\end{array}$ & 75 & 25 \\
\hline 11. & $\begin{array}{l}\text { Are you excited because the lessons delivered by the lecturer } \\
\text { are well received? }\end{array}$ & 16.7 & 83.3 \\
\hline 12. & $\begin{array}{l}\text { Does your lecturer not respond to questions and accept student } \\
\text { opinions? }\end{array}$ & 18 & 82 \\
\hline 13. & $\begin{array}{c}\text { Can the assignments were given by the lecturer help you } \\
\text { understand the lesson? }\end{array}$ & 81.7 & 18.3 \\
\hline
\end{tabular}

Many factors in online learning influences student interest in learning that can be seen in Table 5). By point (10) in Table 5, students' concentration is disturbed in participating in online learning due to limited internet access. The problem often faced by students when they are taking online learning is the disconnected network, so the lecturer's voice is not heard clearly, often out of the virtual room suddenly, and slow in downloading/playing learning videos. It is often experienced by students with locations that are difficult to reach internet signals. In this study, as many as $75 \%$ of students experienced signal interference in attending online learning. Point (11-13) 
provides information that the method of delivering lessons by lecturers and the form of assignments affect student interest in learning. $83.3 \%$ of respondents choose that the lessons in online learning are not well received. During online learning, there are too many subjects and assignments to be done on the same day that they find it difficult to stay focused. The results of Nambiar's research support this finding where students felt that online learning is not effective, lecturers run through the syllabus and students feel they are being overloaded with information (Nambiar, 2020). It states that students' interest in learning is related to exciting learning design. Attractive learning design can trigger student interest in learning.

Enthusiasm is also an indicator of student interest in online learning. The level of enthusiasm in online learning is presented in Table 6.

Table 6. Enthusiasm in Online Learning

\begin{tabular}{|c|c|c|c|}
\hline \multirow{2}{*}{ No. } & \multirow{2}{*}{ Questions } & \multicolumn{2}{|c|}{ Respondent's answer (\%) } \\
\hline & & Yes & No \\
\hline 14. & $\begin{array}{l}\text { Are you more enthusiastic about attending online learning than } \\
\text { classroom learning? }\end{array}$ & 15.3 & 84.7 \\
\hline 15. & Do you prefer online to offline exams? & 32 & 68 \\
\hline
\end{tabular}

The questionnaire results presented in Table 6 show that students are not entirely in-demand online learning activities. In general, students prefer classroom learning compared to online learning. Online learning is less able to accommodate all learning needs. Online learning also has drawbacks in technical issues such as network problems, disconnections, and poor audio and video quality that can interfere with the learning. The research conducted by Nambiar (2020) shows that $23.3 \%$ of students experience various problems when online learning, including students who find it difficult to concentrate, so many distractions at home, and harder to focus during the class. In addition, the online competency exam system (mid-semester and end-semester exams) has a high level of complexity and limited processing time (Jamil \& Aprilisanda, 2020). Online learning seemed too formal and lacked a personal touch, so the learning felt did not lively (Nambiar, 2020).

\section{CONCLUSION}

To suppress the faster spread of Covid-19, universities in Indonesia are implementing online learning. The implementation of online learning elicited various responses from various parties, especially students. $15.3 \%$ of students gave a positive response to online learning and $32 \%$ to online exams. It states that students prefer classroom learning compared to online learning in student attendance, lecturer-student interaction, and technical learning. Weaknesses in the implementation of online learning tend to reduce student interest in attending lectures. Limitations of internet access, lecturer delivery methods, and many workloads are causing the decline in student interest. By knowing students' interest in learning and the factors that cause low interest in learning, lecturers can improve the quality of learning to increase student interest in online 
learning. It is hoped that increasing student interest in learning can also increase the achievement of student learning outcomes.

\section{REFERENCES}

Anhusadar, L. O. (2020). Persepsi Mahasisw PIAUD terhadap Kuliah Online di Masa Pandemi Covid-19. KINDERGARTEN: Journal of Islamic Early Childhood Education, 3(1), 44-58.

Basilaia, G., \& Kvavadze, D. (2020). Transition to Online Education in Schools during a SARS-CoV-2 Coronavirus (COVID-19) Pandemic in Georgia. Pedagogical Research, 5(4), 1-9

Bauerlein, M. (2008). Online literacy is a lesser kind: Slow reading counterbalances Web skimming, The Chronicle of Higher Education, 55(4).

Bye, D., Pushkar, D., \& Conway, M. (2007). Motivation, interest, and positive affect in traditional and nontraditional undergraduate students. Adult Education Quarterly, 57(2), 141-158

Clerkin, K. J., Fried, J. A., \& Raikhelkar, J. (2020). Coronavirus Disease 2019 (COVID-19) and Cardiovascular Disease. Circulation.

Cucinotta, D., \& Vanelli, M. (2020). WHO Declares COVID-19 a Pandemic. Acta Bio-Medica: Atenei Parmensis, 91(1), 157-160.

Gumanti, D., \& Teza, S. D. (2021). Analisis Tingkat Minat Belajar Mahasiswa Pendidikan Ekonomi dalam Perkuliahan Daring Masa Pandemi Covid 19. EDUKATIF: JURNAL ILMU PENDIDIKAN, 3(4), 16381646.

Gunawan, Suranti, N. M. Y., \& Fathoroni. (2020). Variations of Models and Learning Platforms for Prospective Teachers during the COVID-19 Pandemic Period. Indonesian Journal of Teacher Education, 1(2), 61-70.

Hermansyah, F. I. (2020). Pengambilan Kebijakan oleh Swedia dan Indonesia terhadap Pandemi Covid-19. Journal of Virology, 1-14.

Hidi, S., \& Ainley, M. (2002). Interest and adolescence. In F. Pajares \& T. C. Urdan (Eds.), Academic motivation of adolescents (pp. 247-275). Greenwich, CT: Information Age Publishing

Hikmat, Hermawan, E., Aldim, \& Irwandi. (2020). Efektivitas pembelajaran daring selama masa pandemi Covid-19: Sebuah survey online.

Hung, M. L., \& Chou, C. (2015). Students' perceptions of instructors' roles in blended and online learning environments: A comparative study. Computers and Education, 81, 315-325

Jamil, S. H. \& Aprilisanda, I. D. (2020). Pengaruh Pembelajaran Daring Terhadap Minat Belajar Mahasiswa Pada Masa Pandemik Covid-19. Behavioral Accounting Journal, 3(1), pp. 37-46.

Kemendikbud. (2020). Surat Edaran Kementerian Pendidikan dan Kebudayaan Direktorat Jendral Pendidikan Tinggi Nomor 1 Tahun 2020 tentang Pencegahan Penyebaran Covid-19 di Perguruan Tinggi. Jakarta.

Kemenkes RI. (2020). Pedoman Pencegahan dan Pengendalian Coronavirus Disease (COVID-19). Dalam Direktorat Jendral Pencegahan dan Pengendalian Penyakit.

Khasanah, D. R. A. U., Pramudibyanto, H., \& Widuroyekti, B. (2020). Pendidikan dalam Masa Pandemi Covid-19. Jurnal Sinestesia, 10(1), 41-48.

Kurniawan, D. E. \& Makin. (2021). Pengaruh Metode Pembelajaran Daring Terhadap Minat Belajar Mahasiswa Di Masa Pandemi Covid-19. Jurnal Education and Development, 9(2), pp. 47-51.

Kusumaningrum, B., Kuncoro, K. S., \& Arigiyati, T. A. (2020). Pendampingan Orangtua Dalam Pembelajaran Daring Di Sekolah Dasar. INVENTA: Jurnal Pendidikan Guru Sekolah Dasar, 4(2), $142-$ 150.

Kusumaningrum, B., Kuncoro, K. S., Sulistyowati, F., \& Arigiyati, T. A. (2021). Meningkatkan Minat Belajar Daring Selama Masa Pandemi Covid-19

Kusumaningrum, B., \& Wijayanto, Z. (2020). Apakah Pembelajaran Matematika Secara Daring Efektif? 
EDUMATIKA : Jurnal Riset Pendidikan Matematika

(Studi Kasus pada Pembelajaran Selama Masa Pandemi Covid-19). Kreano, Jurnal Matematika KreatifInovatif, 11(2), 136-142.

Laprairie, K. N. \& Hinson, J. M. (2006). When Disaster Strikes, Move Your School Online. Journal of Education Technology Systems, 35(2), 209-214.

Limbong, T., \& Simarmata, J. (2020). Menentukan Matakuliah yang Efektif Belajar Daring (Belajar dan Ujian) dengan Metode Multi-Attibute Utility Theory (MAUT). Jurnal RESTI (Rekayasa Sistem Dan Teknologi Informasi), 4(2), 370-376.

Nadeem, S. (2020). Coronavirus COVID-19: Available Free Literature Provided by Various Companies, Journals, and Organizations around the World. Journal of Ongoing Chemical Research, 5(1), 7-13.

Nambiar, D. (2020). The impact of online learning during COVID-19: students' and teachers' perspective. The International Journal of Indian Psychology, 8(2), 783-793.

Pratiwi, E. W. (2020). Dampak Covid-19 Terhadap Kegiatan Pembelajaran Online di Sebuah Perguruan Tinggi Kristen di Indonesia. Perspektif Ilmu Pendidikan, 34(1), 1-8.

Saifuddin, M. F. (2018). E-learning dalam Persepsi Mahasiswa. Jurnal VARIDIKA, 29(2), 102-109.

Santika, D., Sutisnawati, A. and Uswantun, D. A. (2020). Analisis Minat Belajar Matematika Berbasis Daring. Jurnal Ilmu Pendidikan Dasar, 3(2), p.30.

Setiawan, A. R. (2020). Scientific Literacy Worksheets for Distance Learning in the Topic of Coronavirus 2019. Reading Academic Article.

Setiawan, A. R., \& Ilmiyah, S. (2020). Students' Worksheet for Distance Learning Based on Scientific Literacy in the Topic Coronavirus Disease 2019 (COVID-19).

Smart, K. L., \& Cappel, J. J. (2006). Students' Perception of Online Learning: A Comparative Study. Journal of Information Technology Education: Research, 5(1), 201-219

Sutriyani, W. (2020). Studi Pengaruh Pembelajaran Daring Terhadap Minat dan Hasil Belajar Matematika Mahasiswa PGSD Era Pandemi Covid-19. Jurnal Pendidikan Dasar: Jurnal Tunas Nusantara, 2(1), 155-165

Taha, M. H., Abdalla, M. E., Wadi, M., \& Khalafalla, H. (2020). Curriculum delivery in Medical Education during an emergency: A guide based on the responses to the COVID-19 pandemic. MedEdPublish, 9.

Tosepu, R., Gunawan, J., Effendy, D. S., Ahmad, L. O. A. I., Lestari, H., Bahar, H., \& Asfian, P. (2020). Correlation between weather and Covid-19 pandemic in Jakarta, Indonesia. Science of the Total Environment.

Van Bruggen, J. (2005). Theory and practice of online learning. British Journal of Educational Technology, 36(1), 111-112

World Health Organization. (2020). Coronavirus Disease 2019 (COVID-19).

Yunitasari, R. \& Hanifah, U. (2020). Pengaruh Pembelajaran Daring terhadap Minat Belajar Siswa pada Masa COVID 19. Edukatif: Jurnal Ilmu Pendidikan, 2(3), pp. 232-243. 